\title{
KESEHATAN MENTAL MASAYARAKAT AKIBAT COVID 19 PASCA BENCANA GEMPA DI KABUPATEN MAMUJU
}

\section{COMMUNITY MENTAL HEALTH DUE TO COVID 19 POST-Earthquake DISASTER IN MAMUJU DISTRICT}

\author{
Zuhriana K. Yusuf ${ }^{1}$, Mohamad Insanul Kamil ${ }^{2}$, Susanti Pakaya ${ }^{3}$, Syamaruddin ${ }^{4}$, Akbar \\ Nur $^{5}$, Eko Maulana Malik Albayan ${ }^{6}$, Afiq Ramadhan ${ }^{7}$ \\ ${ }_{1,2,3,6,7}$ Fakultas Kedokteran Universitas Negeri Gorontalo \\ 4,5 Bulan Sabit Merah Indonesia Provinsi Sulawesi Barat \\ Kontak penulis: yusufzuhriana@yahoo.co.id
}

\begin{abstract}
ABSTRAK
Penelitian ini bertujuan untuk mengetahui gambaran kondisi kesehatan mental Masyarakat akibat COVID-19 pasca bencana gempa di Kabupaten Mamuju Sulawesi Barat. Desain Penelitian yang digunakan dalam penelitian ini adalah metode penelitian survei deskriptif. Populasi adalah Masyarakat yang terdampak bencana gempa di kabupaten Mamuju Sulawesi Barat, dan teknik pengambilan sampel secara Accidental sampling dengan total sampel sebanyak 178 responden. Pengumpulan data berdasarkan kuisioner MHI, yang dikumpulkan melalui google form dan observasi langsung di lapangan. Analisa data dilakukan dengan distribusi frekwensi. Hasil Penelitian didapatkan bahwa Kondisi Mental Masyarakat akibat Covid-9 pasca bencana gempa di Kabupaten Mamuju Sulawesi Barat, dalam kondisi kesejahteraan psikologis sebanyak 88,3 \%, kondisi tekanan psikologis sebanyak 11,3\%, kesimpulannya bahwa Kondisi Mental Masyarakat akibat Covid 19 pasca bencana gempa di Kabupaten Mamuju Sulawesis Barat dalam kondisi kesejahteraan psikologis.
\end{abstract}

Kata Kunci: kesehatan mental; COVID-19; bencana gempa

\section{ABSTRACT}

This study aims to describe the mental health condition of the community due to COVID-19 after the earthquake in Mamuju Regency, West Sulawesi. The research design used in this study is a descriptive survey research method. The population is the community affected by the earthquake in Mamuju district, West Sulawesi, and the sampling technique is accidental sampling with a total sample of 178 respondents. Data collection is based on the MHI questionnaire, which was collected through google form and direct observation in the field. Data analysis is done by frequency distribution. The results of the study found that the Mental Condition of the Community due to Covid-9 after the earthquake in Mamuju Regency, West Sulawesi, was in a state of psychological well-being as many as $88.3 \%$, psychological pressure conditions as much as $11.3 \%$, the conclusion is that the Mental Condition of the Community due to Covid 19 after the earthquake disaster in Mamuju Regency, West Sulawesis, in a condition of psychological well-being.

Keywords: mental health; COVID-19; earthquake disaster 


\section{Pendahuluan}

Corona Virus Disease-19 atau lebih dikenal dengan COVID-19 merupakan salah satu virus varian baru yang oleh World Health Organization (WHO) telah ditetapkan sebagai Kedaruratan Kesehatan Masyarakat yang sangat meresahkan dunia pada tanggal 30 Januari 2020 dan kemudian tanggal 11 maret 2020 ditetapkan sebagai Pandemi (Keliat et al., 2020)

Di Indonesia hingga Senin (22/3/2021) pukul 05.30 WIB, kasus positif Covid-19 berjumlah total 1.460.184. Untuk kasus sembuh terdapat penambahan sebanyak 6.065 orang, sehingga totalnya menjadi 1.290 .790 orang. Sementara, pasien yang meninggal dunia karena infeksi Covid-19 ini juga bertambah sebanyak 103 orang. Maka, jumlah pasien yang meninggal dunia kini jumlahnya menjadi 39.550 orang.

Mewabahnya infeksi virus corona saat ini sangat mempengaruhi tatanan hidup baru dikehidupan masyarakat. Pandemi Covid 19 tidak hanya berdampak pada mereka yang terinfeksi saja, tetapi pada semua masyarakat, baik dari segi ekonomi, kehidupan sosial, kesehatan raga, dan interaksi dengan masyarakat luas. Mental Health atau Kesehatan jiwa menjadi salah satu dampak yang mengancam masyarakat selama pandemi Covid-19 berlangsung.

Dampak positif dengan kondisinya yang sehat jiwa tersebut, maka seseorang dapat menyesuaikan dengan dirinya sendiri, orang lain, masyarakat, dan lingkungannya, sedangkan pada kondisi gangguan kesehatan mental yang terjadi selama pandemi Covid 19 disebabkan karena masyarakat dikelilingi oleh kematian, kemiskinan, kecemasan, isolasi, dan kegelisahan akibat pandemi Covid 19. Banyaknya berita buruk yang diterima membuat masyarakat cemas akan hidup diri mereka sendiri, keluarga, teman dan bahkan lingkungan sekitarnya, akhirnya berdampak pada kurang produktifnya masyarakat sehingga mereka akan merasa menjadi beban hidup dalam keluarga (Diinah \& Rahman, 2020).

Daerah yang terdampak bencana, lebih merasakan akibat dari pandemic covid 19 ini. Pengamat kebencanaan mengatakan pemerintah perlu memikirkan langkah-langkah untuk mengantisipasi bencana alam di saat pandemi virus corona, karena ancaman bencana alam masih mengintai berbagai daerah di Indonesia. Widjo Kongko, pakar tsunami dan peneliti senior Badan Pengkajian dan Penerapan Teknologi (BPPT), mengatakan bila terjadi bencana alam berbarengan dengan wabah "ini jadi sesuatu yang betul-betul berat" (BBC, 2020). Pernyataan Widjo beralasan karena terdata pula lebih dari 1.000 kejadian bencana masih terjadi hingga saat ini. Badan Nasional Penanggulangan Bencana (BNPB) menyatakan pihaknya 'pasti akan memberlakukan protokol Covid-19 dalam penanganan bencana'. Namun kenyataan di lapangan membuktikan pemberlakuan protokol Covid-19 tak semudah itu. Masker saja 'masih sulit' didapatkan warga. Pakar kebencanaan berpendapat perlu ada 'modifikasi protokol dan strategi yang lebih tinggi intensitasnya'.

Mengutip rekap data COVID-19 Dinas Kesehatan Provinsi Sulawesi Barat, per tanggal 6 Februari 2021, jumlah kumulatif positif COVID-19 berjumlah 4.380, naik 73 persen dibandingkan data 14 Januari yang hanya 2.529 kasus (Dinkes Sulbar, 2021). Artinya dalam rentang 23 hari terjadi penambahan 1.851 kasus di enam wilayah kabupaten. Dari angka 
kumulatif 4.380 pada 6 Februari, 2.415 diantaranya dinyatakan sembuh, dirawat 256, menjalani isolasi mandiri 1.625 dan kematian akibat COVID-19 berjumlah 84. Setiap ada guncangan gempa masyarakat itu berbondong-bondong melakukan evakuasi dan ini akan berdampak pada terjadinya transmisi lokal yang berdampak pada tingkat penyebaran yang tentu sedikit membesar. Sementara itu, warga yang khawatir dengan penularan COVID-19 sudah mempertimbangkan pilihan untuk kembali. Mereka berencana untuk membuat tenda terpal sebagai tempat tinggal sementara di halaman rumah mereka yang rusak akibat gempa

COVID-19 memberikan mulple stressors pada kehidupan masyarakat (Wu \& Xu, 2020). Mulai dari kekhawaran akan tertular COVID-19, khawatir akan meninggal dan kehilangan anggota keluarga serta teman. Stres akibat terkena PHK dan mengalami penurunan pendapatan. Kementrian Ketenagakerjaan Republik Indonesia pada tanggal 27 Mei 2020 menyebutkan sebanyak 3.066.567 pekerja telah terdampak COVID-19 di-PHK maupun dirumahkan (Antara, 2020). Laporan media yang berulang-ulang tentang keadaan yang sakit dan meninggal menambah rasa takut dan stres. Hal ini semua yang menyebabkan masyarakat yang tidak mengalami kekhawaran atau depresi sebelum pandemi menjadi memiliki kekhawatiran yang berlebihan dan depresi pada saat pademi.

Survei Global Health Exchange tahun 2017 menunjukkan, ada 27,3 juta orang di Indonesia yang mengalami masalah kejiwaan. Gangguan kejiwaan yang paling tinggi yakni kecemasan (anxiety disorder) di mana jumlah pengidapnya lebih dari 8,4 juta jiwa. Selain itu, ada sekitar 6,6 juta orang yang mengalami depresi, dan 2,1 juta orang yang mengalami gangguan perilaku (Arora et al., 2017). Data Riset Kesehatan Dasar Kementerian Kesehatan tahun 2013 pun menyebutkan bahwa prevelensi gangguan jiwa berat seperti skizofrenia mencapai 1,2 per seribu orang penduduk, artinya ada 1-2 orang yang menderita skizofrenia setiap 1.000 penduduk (Abdi, 2019). Melihat dari angka penderita gangguan mental dalam jumlah besar ini, tentunya memberikan informasi kepada kita bahwa permasalahan tentang gangguan mental merupakan masalah kompleks yang perlu menjadi perhatian khusus.

\section{Metode}

Desain Penelitian yang digunakan dalam penelitian ini adalah metode penelitian survey deskriptif. Populasi adalah Masyarakat yang terdampak bencana gempa di kabupaten Mamuju Sulawesi Barat, dan teknik pengambilan sampel secara Accidental sampling dengan total sampel sebanyak 179 responden. Pengumpulan data berdasarkan kuisioner MHI, yang dikumpulkan

melalui google form dan observasi langsung dilapangan. Analisa data dilakukan dengan distribusi frekwensi.

Kuesioner yang digunakan peneliti adalah Kuesioner Mental Health Inventory (MHI). Kuesioner ini dibuat oleh Veit dan Ware (1983) memiliki 38 butir pertanyaan untuk mengetahui kesehatan jiwa yaitu mengukur psychological distress (tekanan psikologis) dan psychological well-being (kesejahteraan psikologis).

Uji validasi menunjukkan hasil valid dengan korelasi uji releabilitas yang menggunakan koefisian Cronbach's Alpha memiliki hasil 0,92. Sedangkan nilai uji validasi yang pernah dilakukan oleh Jane dan Tim Coombs menggunakan Cronbach's Alph menunjukkan hasil 
berada pada 0,93-0,97. Selain itu uji validasi juga dilakukan oleh Naim (2014) menggunakan face validity dalam penelitiannya berjudul Gambaran Kesehatan Jiwa Mahasiswa Tingkat Pertama Program Studi Ilmu Keperawatan Jurusan Keperawatan Fakultas Kedokteran Universitas Diponegoro didapatkan hasil bahwa semua responden mampu memahami semua item pertanyaan pada kuesioner baku MHI 38. Fadlun Naim melakukan uji validasi ini pada responden yaitu mahasiswa keperawatan Universitas Diponegoro. Untuk itu kuesioner MHI 38 tidak dilakukan uji validasi kembali.

\section{Hasil}

Tabel 1. Distribusi Responden berdasarkan Jenis Kelamin

\begin{tabular}{lll}
\hline Jenis Kelamin & Jumlah & Presentase \\
\hline Laki-Laki & 144 & $19,6 \%$ \\
\hline Perempuan & 35 & $80,4 \%$ \\
\hline Total & 179 & $100 \%$ \\
\hline
\end{tabular}

Tabel 2. Distribusi Responden berdasarkan Pendidikan

\begin{tabular}{lll}
\hline Pendidikan & Jumlah & Presentasi \\
\hline SD & 0 & \\
\hline SMP & 3 & $1,6 \%$ \\
\hline SMA & 52 & $29,1 \%$ \\
\hline PT & 124 & $69,3 \%$ \\
\hline Total & 179 & $100 \%$ \\
\hline
\end{tabular}

Tabel 3. Distribusi Responden berdasarkan Umur

\begin{tabular}{ccc}
\hline Umur & Jumlah & Presentasi \\
\hline$<40$ tahun & 159 & $79,5 \%$ \\
\hline$>40$ tahun & 20 & $20,5 \%$ \\
\hline Total & 179 & $100 \%$
\end{tabular}

Tabel 4. Distribusi Responden berdasarkan Pekerjaan

\begin{tabular}{lll}
\hline Pekerjaan & (n) & $\mathbf{\%}$ \\
\hline ASN & 13 & 7,3 \\
\hline IRT & 6 & 3,4 \\
\hline Wiraswasta & 11 & 6,1 \\
\hline Petani & 1 & 0,6 \\
\hline Perawat & 1 & 0,6 \\
\hline Guru/Dosen & 6 & 3,4 \\
\hline PNS & 13 & 7,2 \\
\hline Pelajar/Mahasiswa & 96 & 53,6 \\
\hline Tidak/Belum bekerja & 32 & 17,8 \\
\hline
\end{tabular}




\begin{tabular}{lll}
\hline Total & 179 & 100 \\
\hline
\end{tabular}

Tabel 5. Distribusi Responden berdasarkan Pernah Terkonfirmasi Covid-19

\begin{tabular}{lll}
\hline Terkonfirmasi Covid-19 & Jumlah & Presentasi \\
\hline Ya & 8 & $4,5 \%$ \\
\hline Tidak & 171 & $95,5 \%$ \\
\hline Total & 179 & $100 \%$ \\
\hline
\end{tabular}

Tabel 6. Distribusi Kesehatan Mental Masyarakat akibat Covid-19 Pasca Bencana Gempa

\begin{tabular}{lll}
\hline Kesehatan Mental & Jumlah & Presentasi \\
\hline Kesejahteraan Psikologis & 158 & $88,3 \%$ \\
\hline Tekanan Psikologis & 21 & $11,7 \%$ \\
\hline Total & 179 & $100 \%$ \\
\hline
\end{tabular}

\section{Pembahasan}

Berdasarkan hasil penelitian pada tabel 6 menunjukkan bahwa dari 179 responden sebanyak 158 orang $(88,3 \%)$ berada dalam keadaan kesejahteraan psikologis, hal ini dikarenakan oleh beberapa faktor, pertama beberapa masyarakat memiliki kepuasan hidup yang baik dalam bulan terakhir ini hal ini terbukti sebagian besar $(39,7 \%)$ menjawab merasa puas dan senang dengan hidup pribadinya.

Psychological well being (kesejahteraan psikologis) merupakan suatu kondisi kesehatan jiwa yang menggambarkan life satisfaction, emotional ties dan general positive affect. Kesejahteraan psikologis dikenal dengan keadaan dimana seseorang bisa mengevaluasi diri (Dewi, 2012).

Life satisfaction (kepuasan kehidupan) umumnya seseorang merasa hidup tanpa beban pikiran dan merasa bebas dari ketegangan kehidupan, merasabahagian sehingga hari-harinya dipenuhi keceriaan, merasa damai dan tenang serta bersyukur dengan kehidupan sekarang. Hal ini sebagaimana digambarkan pada jawaban responden pada kuisioner penelitian yaitu pada kategori Life Satisfaction dimana 75,8\% responden mengatakan bahwa dalam tiga bulan terakhir ini sering merasa bahagia, puas atau senang dengan hidup pribadinya.

Pada Emotional ties (ikatan emosional), hubungan emosional yang dekat antara dua orang dengan dasar adanya kasih sayang, sehingga masing-masing orang merasa mencintai dan dicintai serta merasa disayangi dan dibutuhkan (Al Mutair et al., 2021). Hal ini di gambarkan pada kuesioner kategori General positive affect, sebanyak 61,3\% responden mengatakan merasa masa depan penuh harapan, 62,3\% mengatakan hidup sehari-hari selalu penuh dengan hal-hal menarik dan 72,6\% mengatakan selalu menikmati hal-hal yang dikerjakan.

Pada kategori terakhir yakni General positive affect, berupa emosi dan mood (suasana hati). Mood atau dikenal dengan suasana hati memiliki nilai kualitas tersendiri yaitu bisa bernilai positif dan bisa juga bernilai negatif (Kontaris et al., 2020). Suasana hati (mood) bertahan lebih lama dibandingkan emosi akan tetapi dari segi intensitas kurang dibandingkan emosi Hal ini 
digambarkan oleh $61,3 \%$ responden mengatakan merasa masa depan penuh harapan, dan 72,6\% mengatakan selalu menikmati hal-hal yang dikerjakan. Pada kategori Emotional Ties, 70,9\% responden mengatakan sering merasa disayangi dan dibutuhkan 55,9\% selalu merasa hubungan cinta mencintai terpenuhi.

Berdasarkan hasil penelitian menunjukkan bahwa dari 179 responden sebanyak 21 orang $(11,7 \%)$ mengalami tekanan psikologis. Hal inidikarenakan kontrol emosi yang tidak stabil, hal ini terbukti dari sebagian besar masyarakat menjawab merasa emosinya tidak stabil dalam tiga bulan terakhir ini (70,3\%). Faktor lain yang menurut peneliti dapat mempengaruhi tekanan psikosikologi responden adalah status pekerjaan. Sebagian besar responden merupakan Mahasiswa $(53,6 \%)$ dimana pada masa pandemi yang mengerucut kepada aturan Menteri Pendidikan tentang kebijakan belajar dari rumah, membuat mahasiswa lebih sulit memahami materi perkuliahan dan sebagian besar dosen dimasa sekarang memberi lebih banyak tugas. Hal inilah yang mungkin dapat memicu terjadinya tekanan psikologis.

Tekanan psikologis (psikological disstres) ialah keadaan dimana kondisi kesehatan jiwa seseorang digambarkan dengan tingkat anxiety, loss of behavioral/emotional control, dan depression. Anxiety sendiri menunjukkan tanda dan gejala kecemasan misalkan cemas, khawatir, firasat buruk, takut akan pikirannya sendiri serta mudah tersinggung (Walter et al., 2019). Tekanan psikologis pada kategori anxiety sebagaimana terlihat dari jawaban responden yang masuk di dimana $71,4 \%$ responden menyatakan sering merasakan gugup dan gelisah ketika menghadapi situasi yang mengejutkan, 66,6\% menyatakan selalu merasa cemas, serta sering merasa tegang, $75,3 \%$ menyatakan sering merasa gemetar saat berbuat sesuatu, $73 \%$ menyatakan sering merasa gelisah dan tidak tenang, serta 65,6\% menyatakan sering merasa cemas dan khawatir.

Kecemasan pada dasarnya adalah gangguan psikologi yang dicirikan dengan ketegangan motoric (gelisah, gemetar dan ketidakmampuan rileksi) dan kecemasan yang dialami masyarakat saat ini adalah State anxiety yang merupakan reaksi sementara ataupun berkepanjangan yang timbul pada situasi tertentu, yang dirasakan sebagai suatu ancaman (Rusman et al., 2021). Situasi ini jika terus dibiarkan akan menyebabkan seseorang mengalami kecemasan dan gejala-gejalanya akan selalu tampak selama situasi tersebut.

Pada kategori emotional control, sebanyak 74,7\% menyatakan selalu merasa kesepian, 35,2\% menyatakan kadang-kadang merasa kehilangan akal atau kehilangan kontrol, 67,8\% menyatakan sering tidak dapat mengendalikan pikiran atau emosi dan 35,8\% menyatakan kadangkadang merasa tidak ada yang menarik. Pada kategori depression, 78,8\% responden menyatakan merasa tertekan, dan 67,5\% menyatakan kadang-kadang merasa kecil hati.

Munculnya Psychological distress dipengaruhi oleh dua faktor, yaitu faktor intrapersonal dan faktor situasional (Keles et al., 2020). Selain itu faktor karakteristik individu yang berkontribusi menyebabkan stres adalah umur,jenis kelamin, status perkawinan, dan pekerjaan. Umur berhubungan dengan maturitas atau tingkat kedewasaan, secara teknis maupun psikologis semakin bertambahnya umur seseorang maka akan meningkat kedewasaannya, kematangan jiwanya, dan kemampuan dalam melaksanakan tugasnya. 


\section{Kesimpulan}

Kesimpulannya yaitu bahwa Kondisi Mental sebagian besar masyarakat Kabupaten Mamuju memiliki kesehatan mental pada kategori kesejahteraan psikologis dan hanya sebagian kecil yang mengalami tekanan psikologis.

\section{Referensi}

Abdi, A. P. (2019). Kemenkes Sebut Masalah Kesehatan Jiwa Perlu Disikapi Serius. Tirto.Id.

Al Mutair, A., Alhajji, M., \& Shamsan, A. (2021). Emotional wellbeing in saudi arabia during the covid-19 pandemic: A national survey. Risk Management and Healthcare Policy, 14. https://doi.org/10.2147/RMHP.S279716

Antara. (2020). Kemnaker catat 3 juta pekerja terdampak COVID-19. Antara News.

Arora, G., Russ, C., Batra, M., Butteris, S. M., Watts, J., \& Pitt, M. B. (2017). Bidirectional exchange in global health: Moving toward true global health partnership. In American Journal of Tropical Medicine and Hygiene (Vol. 97, Issue 1). https://doi.org/10.4269/ajtmh.16-0982

Barat, D. S. (2021). Update Data Covid-19 Provinsi Sulawesi Barat 2021. Dinas Kesehatan Provinsi Sulawesi Barat.

BBC. (2020). Virus corona: Banjir dan letusan gunung berapi jadi ancaman nyata di tengah wabah, pemerintah “masih bahas pembicaraan awal.” BBC News Indonesia.

Dewi, K. S. (2012). Buku Ajar Kesehatan Mental. LPMP Universitas Diponegoro.

Diinah, D., \& Rahman, S. (2020). Gambaran Tingkat Kecemasan Perawat Saat Pandemi Covid 19 di Negara Berkembang dan Negara Maju: A Literatur Review. DINAMIKA KESEHATAN: JURNAL KEBIDANAN DAN KEPERAWATAN, 11(1). https://doi.org/10.33859/dksm.v11i1.555

Keles, B., McCrae, N., \& Grealish, A. (2020). A systematic review: the influence of social media on depression, anxiety and psychological distress in adolescents. In International Journal of Adolescence and Youth (Vol. 25, Issue 1). https://doi.org/10.1080/02673843.2019.1590851

Keliat, B. A., Marliana, T., Windarwati, H. D., Mubin, M. F., Sodikin, M. A., Kristaningsih, T., D, A. P., Trihadi, D., \& Kembaren, L. (2020). Dukungan Kesehatan Jiwa dan Psikososial COVID-19 : Keperawatan Jiwa. In 30 April 2020.

Kontaris, I., East, B. S., \& Wilson, D. A. (2020). Behavioral and Neurobiological Convergence of Odor, Mood and Emotion: A Review. In Frontiers in Behavioral Neuroscience (Vol. 14). https://doi.org/10.3389/fnbeh.2020.00035

Rusman, A. D. P., Umar, F., \& Majid, M. (2021). Kecemasan Masyarakat Selama Masa Pandemi Covid-19. Jurnal Kesmas (Kesehatan Masyarakat) Khatulistiwa, $8(1)$. https://doi.org/10.29406/jkmk.v8i1.2554

Walter, N., Nikoleizig, L., \& Alfermann, D. (2019). Effects of Self-Talk Training on Competitive Anxiety, Self-Efficacy, Volitional Skills, and Performance: An Intervention 
Study with Junior Sub-Elite Athletes. Sports. https://doi.org/10.3390/sports7060148

Wu, Q., \& Xu, Y. (2020). Parenting stress and risk of child maltreatment during the COVID-19 pandemic: A family stress theory-informed perspective. Developmental Child Welfare, 2(3). https://doi.org/10.1177/2516103220967937 